\title{
Can Asia Help Biden?
}

Abstract A strong, self-confident America is needed to resume its leadership role. Asia has a role to play-if the US is prepared to listen.

Ask not what America can do for you! Ask rather what you can do for America.

If US President Joe Biden were in a position to send a sincere and honest message to the rest of the world in his recent inaugural address, these are the words he should have used-echoing the famous words of John F. Kennedy, exactly 60 years ago, when he said: "Ask not what your country can do for you-ask what you can do for your country."

Instead, because American presidents are prisoners of American political tradition, President Biden had to say: "We can make America, once again, the leading force for good in the world."

The sad reality is that the United States can no longer provide the world with unquestioned leadership.

American leadership has benefited the world: The multilateral rules and institutions it generated after World War II have prevented World War III; the open markets of America helped the East Asian tigers and China to succeed; the US Navy enabled freedom of navigation. But all this strong global leadership required a strong, self-confident America, one that Kennedy's stirring rhetoric could rouse 60 years ago.

Sadly, Mr. Donald Trump has left a broken, deeply divided America that has neither the spirit nor the will to lead the world. Any illusions that a strong, selfconfident America would bounce back after Mr. Biden's election were wiped out on Jan 6, when the world saw an unruly mob storm the US Capitol, in part because of the implicit encouragement of Mr. Trump himself.

This is why Dr. Richard Haass, president of the Council on Foreign Relations, America's most prestigious foreign policy think tank, tweeted that day: "No one in the world is likely to see, respect, fear, or depend on us in the same way again. If the post-American era has a start date, it is almost certainly today."

Originally published in The Straits Times, Jan 22, 2021 
British journalist Martin Wolf is equally pessimistic. As he wrote in the Financial Times: "The US republic has survived the test of Trump. But it still needs to be saved from death."

The big question that the rest of the world, including Asia, faces with President Biden's inauguration, is whether it is in the world's (or Asia's) interest to see America continue to decline and weaken, or if we should instead help America to recover.

The answer is obviously the latter: The world is better off with a strong, selfconfident America.

Yet, Asia (or the world) can help America only if it believes that it needs help. Sheer pride will make it difficult for Americans to accept that they need help, even though thoughtful Americans, like political scientist Francis Fukuyama, acknowledge that America has some serious internal healing to do.

Dr. Fukuyama said that the US is "divided, internally preoccupied, and contradicting its own democratic ideals".

America's internal problems are deep and structural. As I document in Has China Won?, they range from the deeply plutocratic political system that has become entrenched to the "sea of despair" that has emerged among the white working classes, who sadly and unwisely supported Mr. Trump in their anger.

No magic wand can wave away all these deep structural problems.

There is no question that President Biden is doing the right things to help America get back on the road. He has announced the following measures in the first 100 days of his term: a US\$1.9 trillion (S\$2.5 trillion) coronavirus relief package, 100 million vaccine doses, a US\$15-an-hour minimum wage increase, extending a pause on student loan payments, and extending nationwide restrictions on eviction. Let's hope that these internal healing measures work.

Equally important, President Biden should avoid painful and demanding external commitments. The wisest thing that he could do to help both America and the world heal from the Covid-19 rampage is to press the pause button on the US-China geopolitical contest. It would be sheer common sense to do this.

Unfortunately, given the toxic anti-China mood in America, his hands are tied. If he is seen to be soft on China, he will be excoriated. Thus, publicly, he must appear to be tough on China.

Surprisingly, President Biden said nothing about China in his inaugural speech.

However, his Cabinet appointees_-including Dr. Janet Yellen for treasury secretary, Mr. Antony Blinken for secretary of state, and Ms. Avril Haines for director of national intelligence - have criticized China strongly in their Senate confirmation hearings.

Ms. Haines said: "China is a challenge to our security, to our prosperity, to our values across a range of issues, and I do support an aggressive stance, in a sense, to deal with the challenge that we're facing."

Yet, even though the logical and sensible pause button is out of Mr. Biden's reach, he can still rebalance the US-China contest.

If former president Barack Obama opted for $60 \%$ cooperation and $40 \%$ competition with China, while Mr. Trump essentially went for $90 \%$ competition and 
$10 \%$ cooperation, President Biden can at least go for $60 \%$ competition and $40 \%$ cooperation.

\section{Golden Opportunity}

Yet, President Biden cannot achieve this rebalancing on his own. He needs the help of Asia. All this provides ASEAN (including Singapore) with a golden opportunity.

To win political support for a more rational China policy, Mr. Biden needs political cover. ASEAN can provide political cover by collectively calling on both China and the US to first focus on working together to solve common and pressing problems like Covid-19 and climate change.

The most sensible thing Mr Biden could do is to send his senior diplomats to East Asia on a "listening" mission.

Indeed, all good diplomacy begins with listening and understanding. Here, there is no question what President Biden's diplomats will hear from South-east Asians: They want a strong American presence in South-east Asia, but they also do not want to be forced to choose between America and China.

The former Indonesian ambassador to the US, Dr. Dino Patti Djalal, put it well when he said: "Today, South-east Asians want to get along with the US and China, but they also want the US and China to get along, at least in their region. Is that too much to ask?".

He added: "We don't want to be duped into an anti-China campaign".

Fortunately, President Biden has chosen as his Asian "czar" Mr Kurt Campbell, a seasoned and experienced diplomat. During the Covid-19 lockdown period, he and I partnered together in a debate organized by Intelligence Squared the US to argue in favor of a motion, "Coronavirus will reshape the world order in China's favor".

In the debate, he said: "We expect a country to provide domestic capacity and demonstrate competence in terms of dealing with the pandemic. No one would argue that the US has been able to do anything of this kind. It's been a tragedy to see the incompetence with which the US has dealt with the issue".

"We would expect that the leading nation would be able to provide support in terms of PPE (personal protective equipment) and equipment. We've seen nothing of the sort from the US".

"What we see in contrast is China, even though this is where the virus originated; since that time they've been reaching out, providing equipment and support to a variety of countries around the world".

He added: "After the coronavirus has swept the planet, it is undeniable that China has taken advantage of the situation, has moved forward and everyone sees that America has been missing in action." Changing priorities.

Mr. Campbell is also a good listener. If he came to South-east Asia, he would hear another clear message on the priorities of ASEAN.

All countries have to prioritize politics, economics, and security in their international affairs. America tends to prioritize the security dimension the most, followed 
by politics and economics. China prioritizes economics, followed by politics and security. There is no question that the priorities of ASEAN are closer to those of China than America.

Given the social and economic travails of the US, and the "sea of despair" faced by its working classes, it would now be in America's self-interest to also put economics ahead of security.

Unwisely, America has spent over US $\$ 5$ trillion fighting futile post-9/11 wars. If this US $\$ 5$ trillion had been spent on the bottom $50 \%$ of American society, each citizen in this group would have received a cheque for US $\$ 30,000$. This is a very significant amount, especially since $60 \%$ of Americans do not have access to US $\$ 400$ in case of an emergency.

In short, contrary to the conventional wisdom in Washington, which is strongly in favor of accelerating the geopolitical contest against China, it would be wiser for America to at least press the pause button on this contest and focus on getting both the American and global economies back on track.

ASEAN (and Singapore) has a golden opportunity to help Mr Biden by providing him with the necessary political cover to pursue a more sensible approach in USChina relations. By doing this, ASEAN will also repay America a major debt. Without American support and backing, ASEAN could not have been successfully launched in 1967. Now it is ASEAN's turn to help America successfully re-launch itself.

Open Access This chapter is licensed under the terms of the Creative Commons AttributionNonCommercial-NoDerivatives 4.0 International License (http://creativecommons.org/licenses/bync-nd/4.0/), which permits any noncommercial use, sharing, distribution and reproduction in any medium or format, as long as you give appropriate credit to the original author(s) and the source, provide a link to the Creative Commons license and indicate if you modified the licensed material. You do not have permission under this license to share adapted material derived from this chapter or parts of it.

The images or other third party material in this chapter are included in the chapter's Creative Commons license, unless indicated otherwise in a credit line to the material. If material is not included in the chapter's Creative Commons license and your intended use is not permitted by statutory regulation or exceeds the permitted use, you will need to obtain permission directly from the copyright holder.

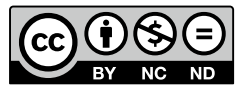

